
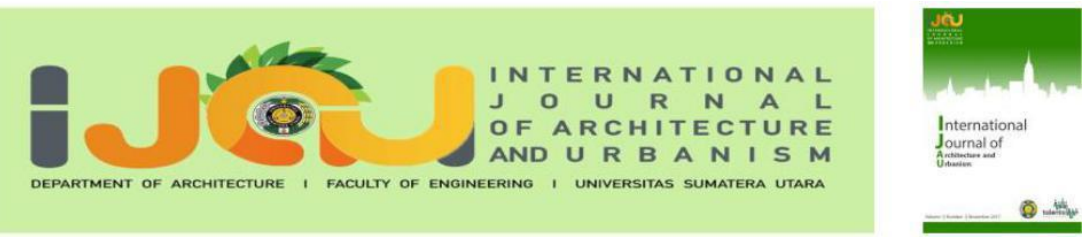

\title{
The Green Architecture Approach to Natural School at Suburb
}

\author{
Samosir, S.N ${ }^{1}$, Harsidani, D.D. ${ }^{1}$ \\ ${ }^{1}$ Department of Architecture, Faculty of Engineering, Universitas Sumatera Utara, Medan, Indonesia
}

\begin{abstract}
Natural school is an educational institution that can answer the environmental problems and rigid education system problems with natural nuances. The green architecture approach is used as a design approach to achieve natural school goals that provide an understanding of how awareness of nature is applied in the school. The green architectural approach can be applied by the use of environmentally friendly local materials, natural ventilation, environmentally friendly waste management, and the use of the minimum natural resource. This study uses a glass box and a black box design method. The result of this study is a natural school design that is environmentally friendly and healthy in the suburb of Medan, Indonesia.
\end{abstract}

Keywords: architecture, environmentally friendly, green architecture, natural school.

\section{Introduction}

The development of times and technology provides changes, especially in the current state of the environment. Household and industrial waste are dumped carelessly so that it pollutes the air, soil, and water. This negative culture must be stopped immediately by providing knowledge of the importance of the environment to today's young generation. Natural schools will teach the knowledge of the importance of nature and the environment. Also, natural schools also use an education system that practices theory directly. Many students do not like the conventional school education system. Children are forced to study indoors to transfer knowledge that only contains theory. Some children prefer the school's natural education system to the conventional school education system. They can learn in the wild and experience the lessons they get directly. They are more excited and not bored.

The issue of the green environment and global warming increasingly enlivened today. Human neglect and indifference to nature cause environmental damage and global warming. Natural schools must be close and care about current environmental problems. Natural schools can

\footnotetext{
*Corresponding author at: Department of Architecture, Faculty of Engineering, Universitas Sumatera Utara, Jalan Perpustakaan Gedung J07, Medan 20155, Indonesia

E-mail address : devin.defriza@usu.ac.id
} 
contribute to this problem by doing several ways like the use of environmentally friendly, materials, efficiency in energy use, and protecting natural resources. The green architecture approach to natural schools is expected to provide answers to current environmental problems.

\section{Literature Review}

\section{Function and Architecture Theory}

School is an institution or building that is used as a place to receive and give lessons [1]. Natural schools are schools that use the concept of education in the form of action learning or active learning based on the universe. Learning objects can be seen by students by going to the field directly. The concept of natural schools provides a pleasant experience by using nature as a learning tool. The advantages of natural schools compared to conventional schools is natural schools do not make children just fixated on theory [2].

Based on Minister of National Education Regulation No.24 of 2007, some minimum standards can be used in determining the location for educational facilities and infrastructure (Table 1).

Table 1. Location Criteria for Education Facilities and Infrastructure

\begin{tabular}{ll}
\hline \multicolumn{1}{c}{ Criteria } & \multicolumn{1}{c}{ Details } \\
\hline Land Area & $\begin{array}{l}\text { The area of land for educational facilities must be a large number of } \\
\text { students }\end{array}$ \\
\hline $\begin{array}{l}\text { Location } \\
\text { Security }\end{array}$ & $\begin{array}{l}\text { Land for educational facilities must be safe and avoid hazards that can } \\
\text { threaten the health and safety of the soul. The land must also have adequate } \\
\text { access to safety in an emergency. }\end{array}$ \\
\hline $\begin{array}{l}\text { Land } \\
\text { Conditions }\end{array}$ & $\begin{array}{l}\text { The average land slope is less than 15\%, not within the river and railroad } \\
\text { borderlines. }\end{array}$ \\
\hline Pollution & The land is protected from water pollution, noise, air pollution. \\
\hline Regulation & $\begin{array}{l}\text { Land follows the District / City Spatial Plan that regulated in a Regional } \\
\text { Regulation or other more binding regulations. Land use must also get } \\
\text { permission from the local government. }\end{array}$ \\
\hline
\end{tabular}

(Source: Minister of National Education Regulation No.24 of 2007)

Green architecture is a theme in architectural science that is formed as a consequence of sustainable architecture. Building design using the theme of green architecture is expected to allow humans able to live and carry out all their activities continuously on this earth. The green architectural approach can be seen in natural resources that are little used by humans to guarantee human survival in the future [3]. 


\section{Concept}

Natural schools teach students how to love the environment and nature. Students not only learn how to take care of the environment in theory but can feel its application in their school directly. The green architectural approach to natural schools will create a comprehensive relationship of buildings, built environment, and area. The concept of green architecture has criteria like saving the use of natural resources, minimizing the emergence of negative impact, and increasing the quality of human life [4].

A study in South Africa proved that the temperature at an altitude of one meter above the concrete surface street material was about $4{ }^{\circ} \mathrm{C}$ higher than the temperature above the grass surface with the same height [5]. As a landscape element, plants also influence energy savings in buildings. Trees that function as the shade will reduce the air temperature under its shade. Shade trees can be planted near the walls that exposed to direct sunlight [6]. A study has shown that planting shade trees around residential homes can reduce temperatures by around $3{ }^{\circ} \mathrm{C}$. The decrease in temperature will reduce energy use by $30 \%$ because theoretically, a decrease in temperature of about $1{ }^{\circ} \mathrm{C}$ is equal to energy savings of $10 \%$ [7]. The trees with high and slender types will be able to reduce the temperature. The composition of this tree in large quantities and tightly will disrupt the flow of air into the building. A shade tree with a widecrowned type will be able to reduce the temperature, limit sunlight and not interfere with air flow (Figure 1). However, shade trees with a too thick canopy will limit the overall entry of sunlight so that it will cause humidity in the building.

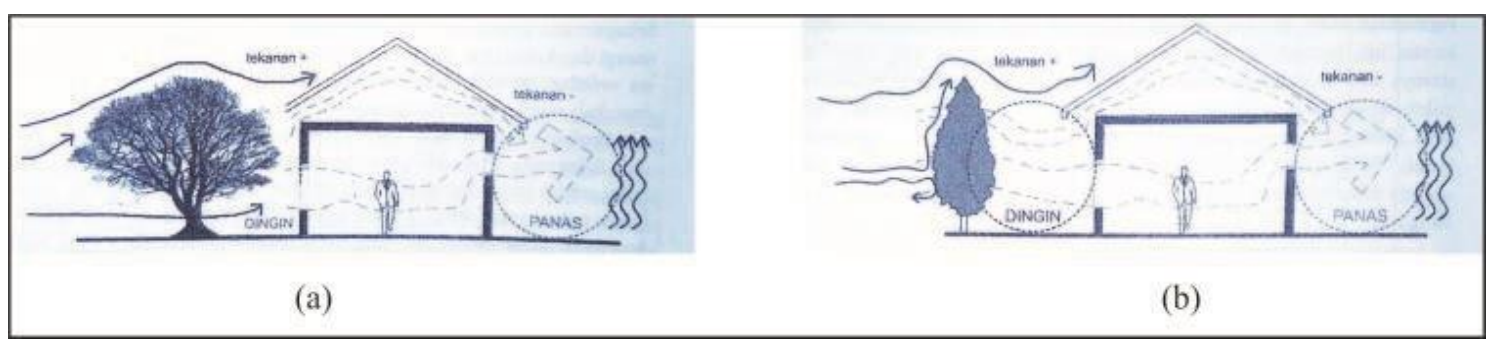

Figure 1. (a) Temperature reduction with vegetation in lush canopy and (b) slim (Source: Christina, E. M., 2013)

The street material in the outer space is needed for the circulation path for vehicles or footpaths. However, this street material should not cover all green areas. The selected street material should be material that can pass and absorb water [6]. The ease of water absorbing into the soil will be very helpful in conserving water and reducing the likelihood of flooding. Grass block can be one solution to these problems. Grass block is a building element from a cement mixture with a hole in the middle that can be filled with grass. Grass blocks are useful to help speed up the absorption of water by the soil through grassy holes [8]. In addition to using street material that can pass water, the building with the concept of a house on stilts is also able to absorb rainwater optimized (Figure 2a). 


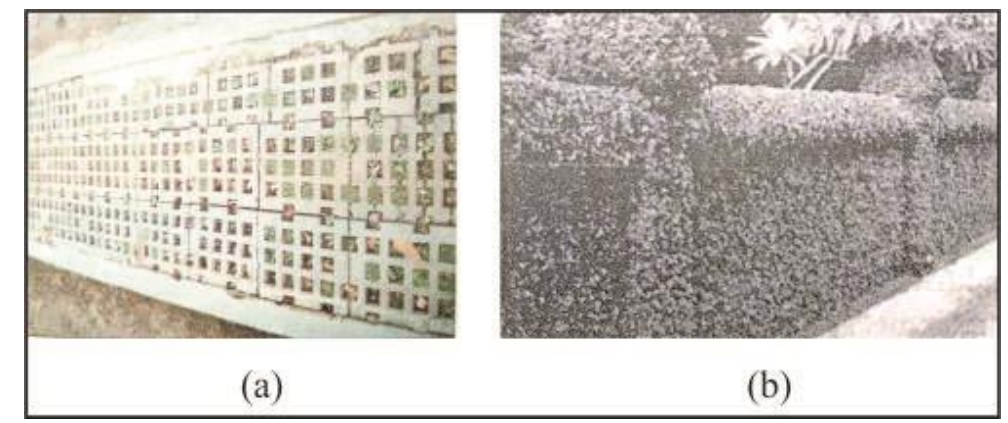

Figure 2. (a) Grass block to prevent flooding, (b) Hedgerows to reduce noise (Source: (a) Karyono, T. H., 2010, (b) Christina, E. M., 2013)

Noise reduction from outside the building will also save energy usage in buildings indirectly. The hedgerows on the front will be able to reduce noise if it is tightly arranged and massive like a brick (Figure 2b). Also, hedgerows are also effective for filtering dust and air pollution [9].

Based on Minister of Public Works Regulation No.30 / PRT / M / 2006, the principle of facilities and accessibility in buildings consist of safety, ease, usefulness, and independence. Circulation of motorized vehicles, non-motorized vehicles, and pedestrians should be separated. This was done because the culture of motorized vehicles never succumbed to pedestrians, especially in Indonesia [10]. The pedestrian path is the path element that forms the city that is used as a barrier from one region/block/district [11]. The pedestrian path that is comfortable for pedestrians is located not too high $(20-30 \mathrm{~cm}$ from the road), the size of the track is not too small, and flat [12].

The process of building mass composition is divided into additive (add) and subtraction (reduction) [13]. The result of additive formation is expected to be able to provide freedom of natural ventilation. Subtraction formation results are expected to provide a lot of shadows to create a shady atmosphere [14]. In addition to additives and subtractions, determining the orientation of the orientation the building's mass will determine the amount of sunlight that affects the building. The wider the area of the building that receives sunlight, the greater the heat that the building will receive (Figure 3). Therefore, the widest building area should face north-south and the smallest building area facing east-west [15].

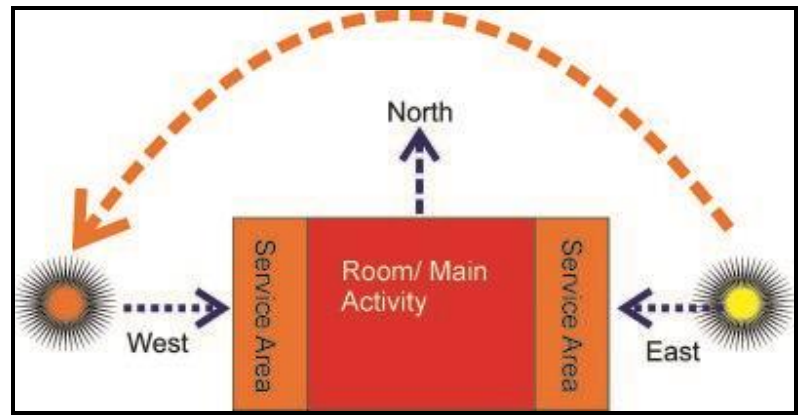

Figure 3. Building orientation concept to reduce heat in the building (Source: Karyono, T. H., 2010) 
The use of environmentally friendly materials in the building mass is one of the principles of green architecture. Bamboo is a local material and natural material that is quickly regenerated compared to wood [9]. In addition to the use of natural materials, vertical garden on the facade are also believed to be able to reduce heat in buildings (Figure 4). A study proves that the installation of a vertical garden with a distance of two meters and a 2-level configuration can reduce the temperature of $1-4{ }^{\circ} \mathrm{C}$ at 10:00 pm o'clock [16].

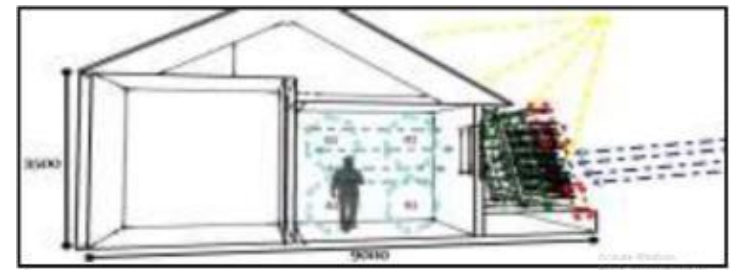

Figure 4. Vertical garden concept to reduce heat in the building (Source: Luddityawan, A. R., Nugroho, A. M., \& Razziati, H. A., 2014)

The roof is the top cover of the building that serves to protect buildings from debris and the influence of climate (cold, heat, and wind) [17]. The choice of roofing material is also a benchmark for green architecture. Consideration in the selection of roofing materials should also pay attention to the surrounding environment. Roofing material that can glare by reflecting sunlight should be avoided. This reflecting roof is able to reflect the sunlight that it receives maximally. Reflection of light or glare will cause disability glare and discomfort glare in people who accidentally see. In addition to causing discomfort for people around, sun reflecting the roof can also interfere with low altitude flights [7].

To get good air flow in the building, the arrangement of space in the building should be made the single layer. Each room will have an inlet window and outlet in the opposite direction, allowing cross ventilation. Cross ventilation is the best solution for buildings without air conditioning. To maximize air flow, vertical ventilation placement also needs to be considered (Figure 5). Ventilation that functions as an inlet should be placed at an altitude of $60-150 \mathrm{~cm}$ to drain air in the human body. Ventilation that functions as an outlet is placed higher than the inlet so that the hot air rising can be removed [18].

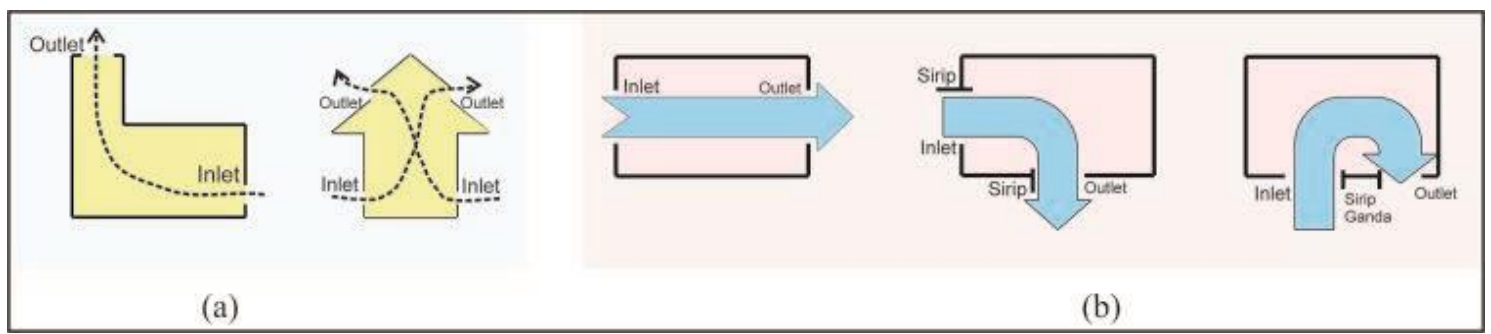

Figure 5. (a) The concept of cross ventilation vertically and (b) horizontally to reduce the temperature in the building (Source: Christina, E. M., 2013) 
U-shaped tread or perforated tread provides the opportunity to create an additional garden in the middle of the building (Figure 6). The existence of this park will allow the entry of light and natural air flow in each room [9].

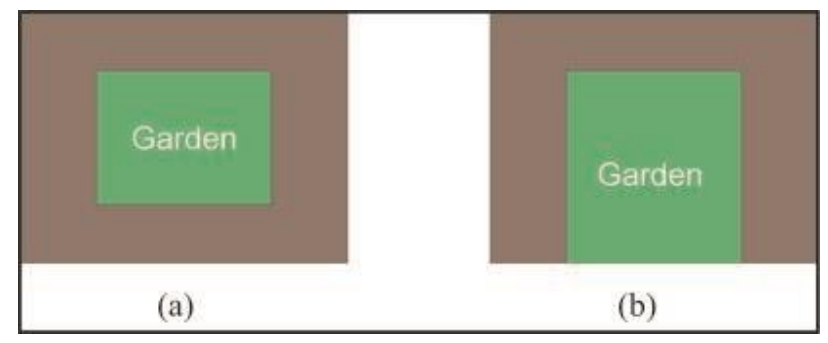

Figure 6. (a) U-shaped and (b) perforated tread will enter sunlight and natural air into the building

(Source: Christina, E. M., 2013)

The building structure serves to solve technical problems in the form of building robustness and aesthetics in the form of building space in buildings [19]. The structure chosen should adjust to the characteristics of the room in the building. The rigid frame structure system can help arrange space, windows, and doors that are on the typical floor or ground floor (Figure 7) [20].

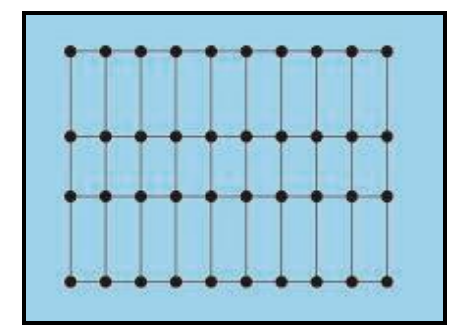

Figure 7. The rigid frame structural system can help arrange space (Source: Tangoro, D., Sukardi, K., \& Somaatmadja, A. S., 2006)

Building waste can be solid and liquid. Buildings with a green architectural approach do not dispose of waste carelessly. Waste should be disposed of in the land itself by processing it first so that the soil is not absorbed directly. WC waste should be distributed first to the septic tank then the waste is channeled to the infiltration well with good quality pipes. The septic tank should be made from materials that are not easily seeped. Tanks that made from fiber or plastic are considered more durable and free of seepage than brick or concrete that coated with antiseepage [6].

In addition to toilet waste, liquid waste also comes from the bathroom, laundry area, and sink. This dirty liquid contains fat and soap so that this waste must be processed first through a foam/ soap catcher (control wells). After going through the control wells, the waste is then channeled to the infiltration well [6]. Making infiltration well does not require large costs, simple construction, and land that does not need to be large [21]. 
Buildings with a green architecture approach must also be responsive to the amount of rainwater runoff that will cause flooding during the rainy season. The solution applied to solve this problem is the use of biopori and rain tanks. The biopori hole is a hole that was intentionally created to maximize the absorption of rainwater to become ground water [9]. Biopori can be placed in a yard that has street materials such as concrete, asphalt and paving blocks [22].

Environmentally friendly electricity can use resources from solar energy. Solar energy can be used through two types of technology, namely photo-voltaic solar, and thermal solar energy [23]. The technology used in general is solar photo-voltaic or often referred to as solar cells. Installation of solar cells on the roof is considered more efficient because it does not require additional land [7].

\section{Methodology}

The initial step taken in this study is to examine how elements of green architecture can be applied to natural schools perfectly. Then, the author collects primary data and secondary data. After that, the author tried to explore the curriculum in natural schools and green architectural elements. The results of the analysis of the natural school curriculum produce the type of facilities needed, the size of the room in the building, and the landscape elements. The results of the analysis of the elements of green architecture are energies saving through the use of materials, building utilities, and natural ventilation. Finally, the combination of space needs and energy savings resulted in a green architectural approach to natural schools.

The initial process of selecting the location was reviewed the Regional Spatial Planning regulation of Medan city in 2010-2030 and explore the characteristics of natural school locations in the suburbs. Based on the Spatial Plan of Medan city in 2010-2030, the development of the dominant education center is in the southern Medan sub-district. The southern part of Medan is cooler than the northern part because it has a higher topography. This regulation also supports the characteristics of natural school locations such as cool places, suburbs, easy access, and many plantations around the location. Based on these data, the author decided to take a location in southern Medan, Indonesia.

\section{Result and Discussion}

\section{Siteplan}

Most shade trees in this natural school design are wide-head trees in the form of fruit trees such as mango trees. Besides being very effective in natural air conditioning, these trees are also able 
to strengthen the image of natural schools. Some trees in this natural school design are placed in the east and west to reduce the heat of the sun (Figure 8).

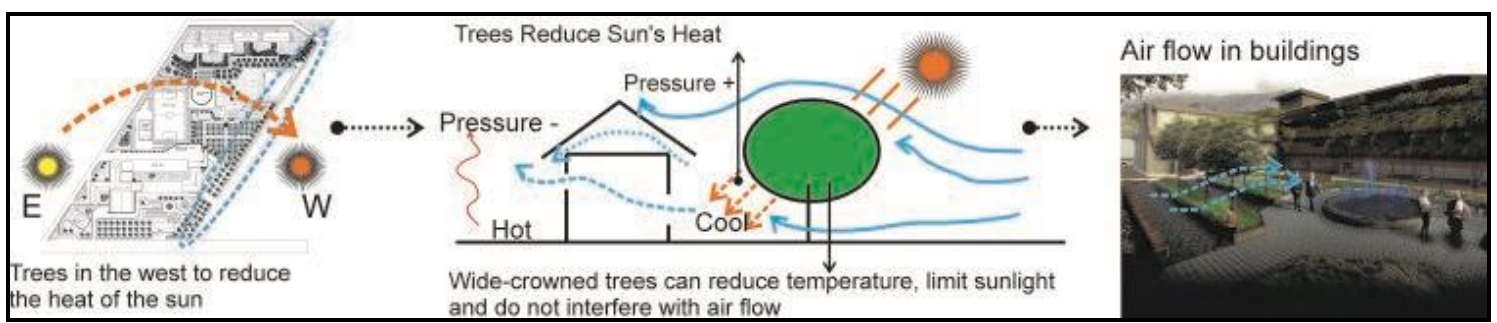

Figure 8. Vegetation design in the natural school for energy saving

The Street material used in this natural school design is the arrangement of natural rocks (Figure 9). Besides being very environmentally friendly, this material is also able to strengthen the image of natural schools. The concept that adds to the ease of water to be absorbed into the soil is the concept of a stilt house. The house stage concept allows water to be absorbed into the soil optimally.

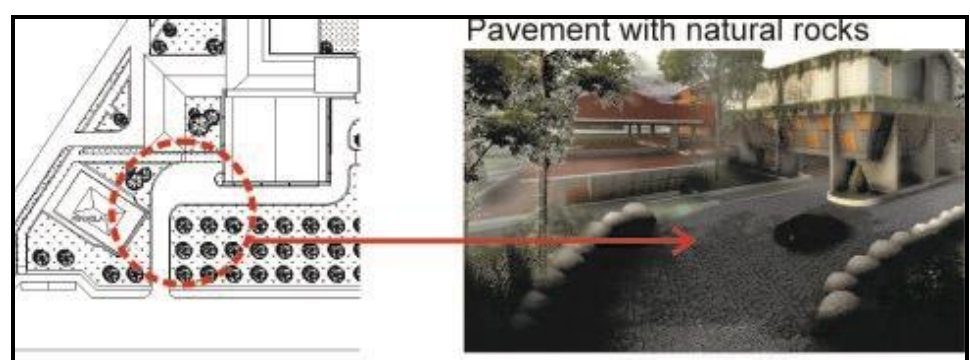

Figure 9. Natural stone arrangement as street material to prevent flooding in the natural school

The selection of high-density hedgerows on the front of the natural school design is a practical solution in solving air pollution and noise problems. Indirectly, it will save energy in natural school buildings (Figure 10).

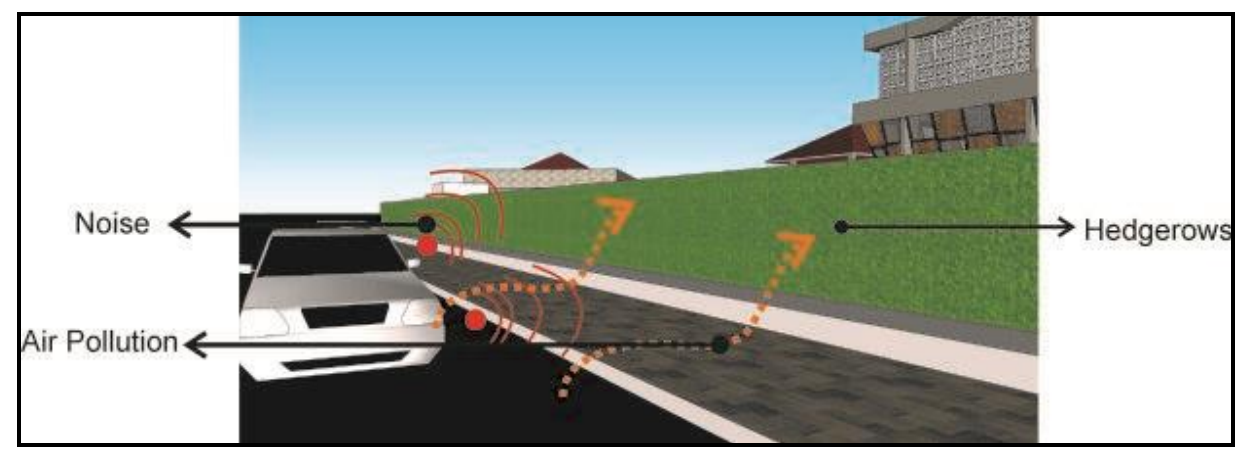

Figure 10. Hedgerows as an energy saver

\section{Circulation}

Circulation in this natural school design is divided into two main parts consist of the pedestrian and motorized vehicle lanes. The pedestrian route is divided into pedestrian lanes with roof cover and regular pedestrian paths (Figure 11). Motorized vehicle lanes are divided into three lanes consist of the main lane, school bus lane, and service lane. 


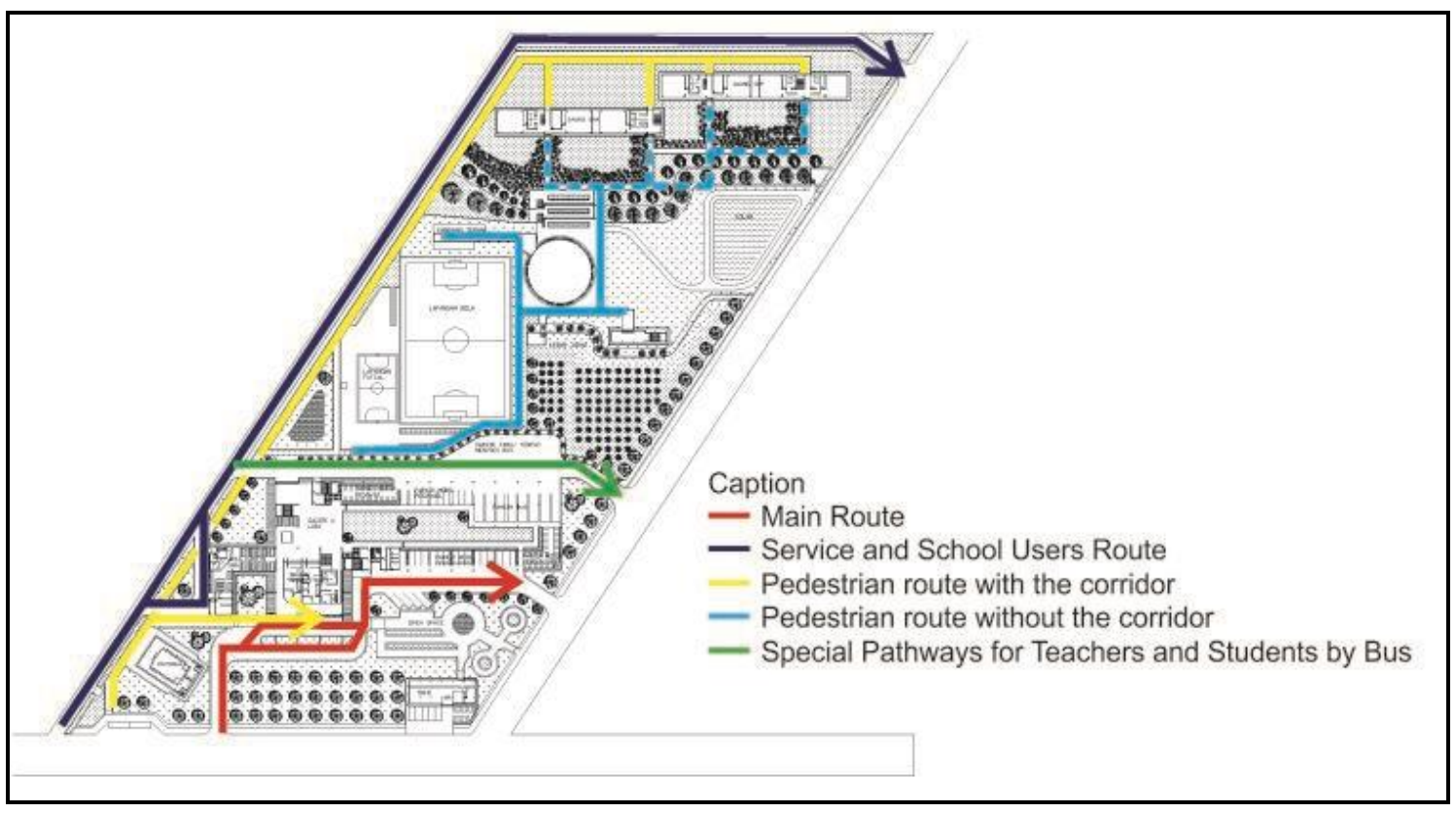

Figure 11. Circulation concept in this natural school design to prevent cross circulation

\section{Mass Composition}

The orientation of each of the widest areas of building mass in natural school faces north and south as a form of approach to green architecture (Figure 12).

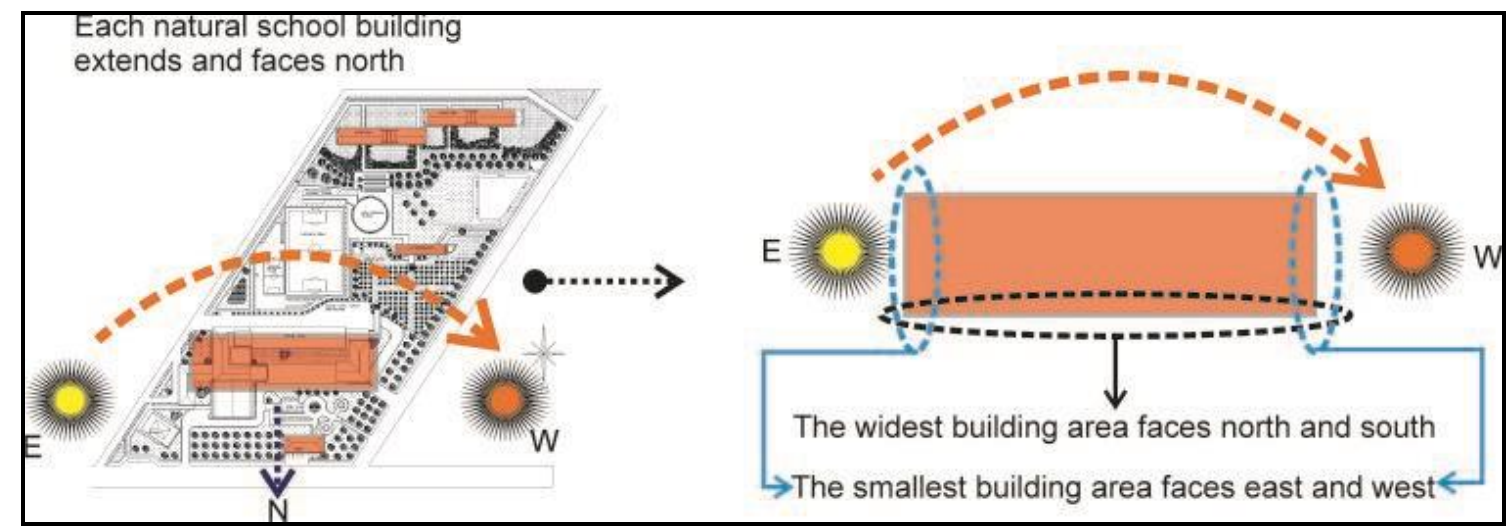

Figure 12. The concept of energy saving through building orientation

Facades in natural school buildings use bamboo materials. In addition to using bamboo materials, natural school building facades are also using vertical plants in the form of hydroponic plants. This vertical plant is expected to reduce temperature and provide coolness in the room. Natural school designs use protective openings in the form of a local canopy to reduce heat and sunlight into the building. In addition to reducing the heat of the sun, this local canopy also serves to protect openings from rainwater seepage. The material on the roof of this natural school design uses clay tiles as a roof cover (Figure 13). In addition to displaying a natural impression (strengthening the characteristics of natural schools), this material is also very environmentally friendly. 


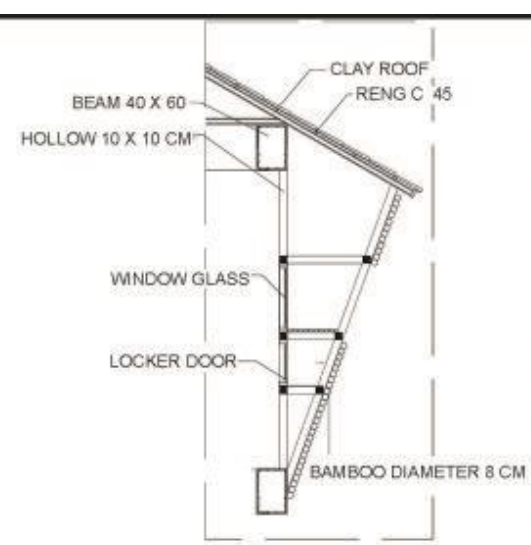

(a)

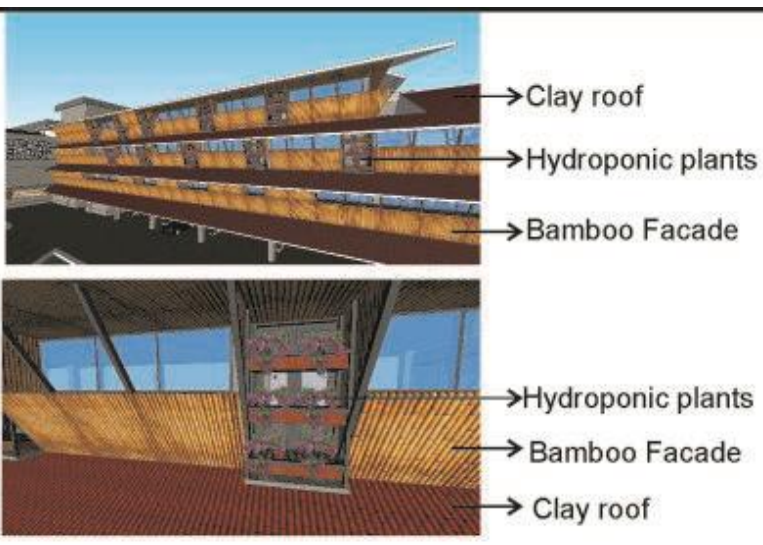

(b)

Figure 13. (a) Details and (b) perspectives that are environmentally friendly on natural school

\section{Inner Spatial}

Deep space in the design of natural schools with a green architectural approach is maximized by the use of natural air without air conditioning. Buildings in natural school design apply the principle of cross ventilation for natural ventilation. Ventilation holes are made of the bamboo material to give a natural impression in natural schools.

The formation of mass in the design of natural schools is a building with holes in the inner court. Natural school design applies inner court and stilt house concept. This concept will make the airflow in the building better. Cold air will enter from the bottom of the building and bring out hot air up through the inner court (Figure 14).

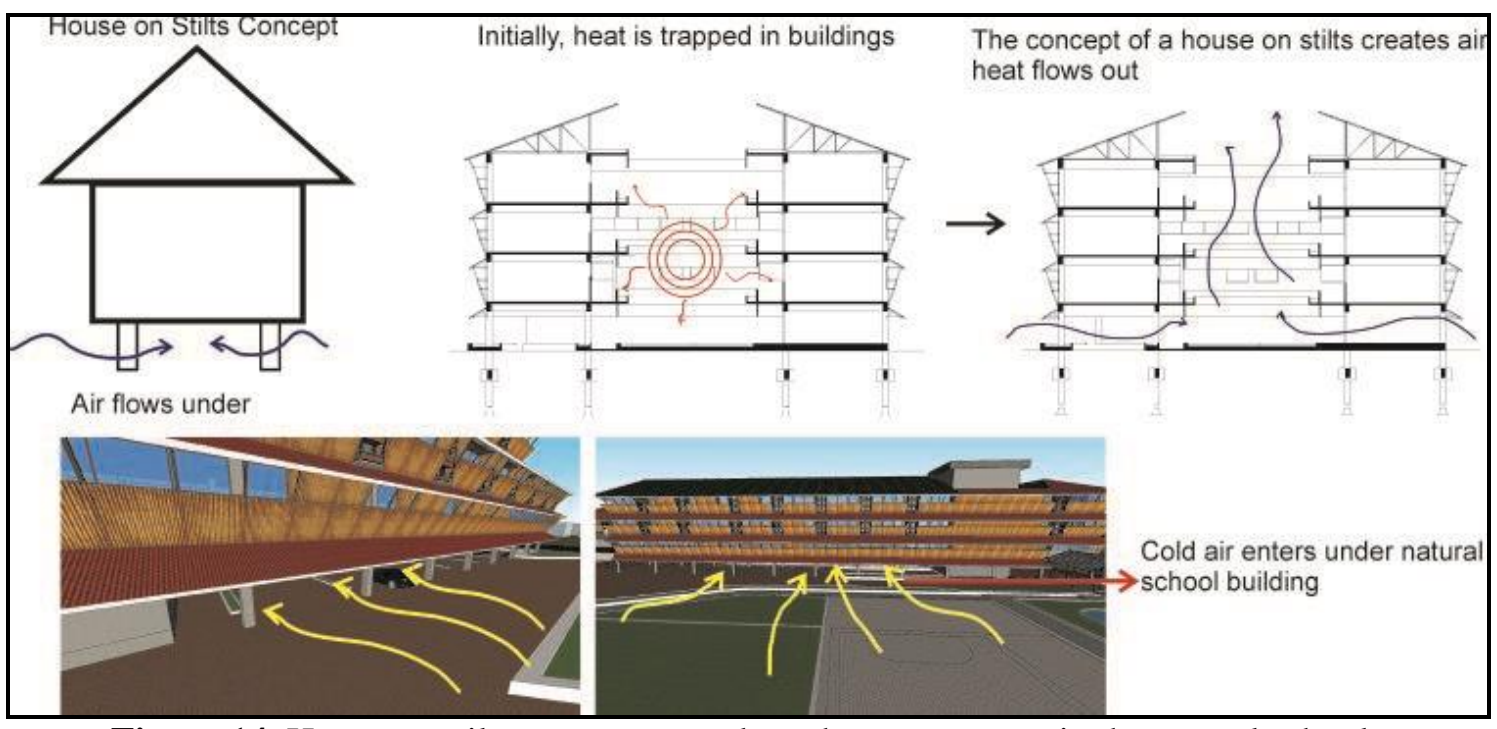

Figure 14. House on stilt concept can reduce the temperature in the natural school.

\section{Structure}

The structure of the natural school building uses an $8 \mathrm{mx} 8 \mathrm{~m}$ grid system. The grid system is very suitable with the functions of classrooms in the building. 


\section{Utility}

The waste that is going to the infiltration pond can pollute the soil because it is not completely clean and still contains chemicals. Therefore, the design of the natural school is equipped with Sewage Treatment Plant so that the water that goes to the infiltration pond does not pollute the soil. In addition to the Sewage Treatment Plant, natural school designs are equipped with biopori and rainwater tanks to prevent flooding. In addition to preventing flooding, rainwater tanks are also useful for saving water in natural schools (Figure 15).

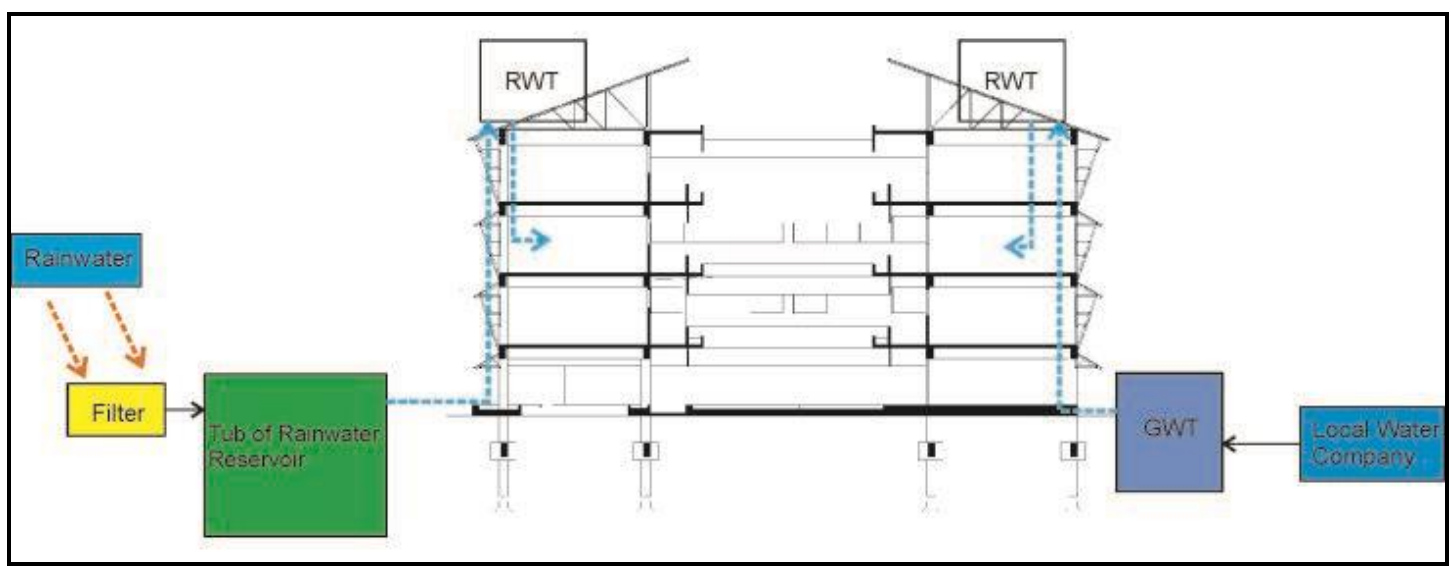

Figure 15. Energy savings with the use of rainwater

\section{3d Impression}

The green architectural approach can be seen in the exterior impression and interior impression created in the natural school (Figure 16).

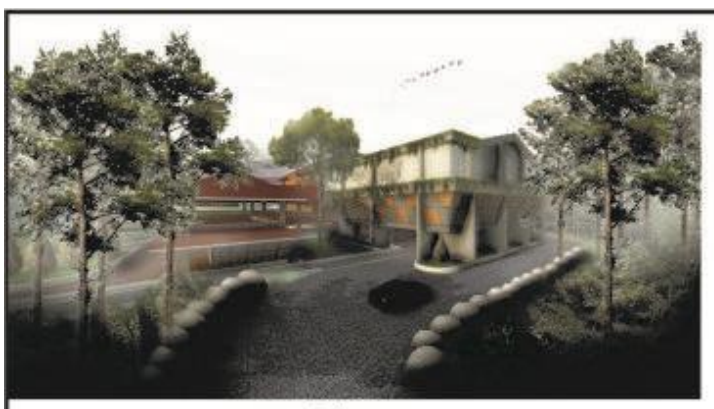

(a)

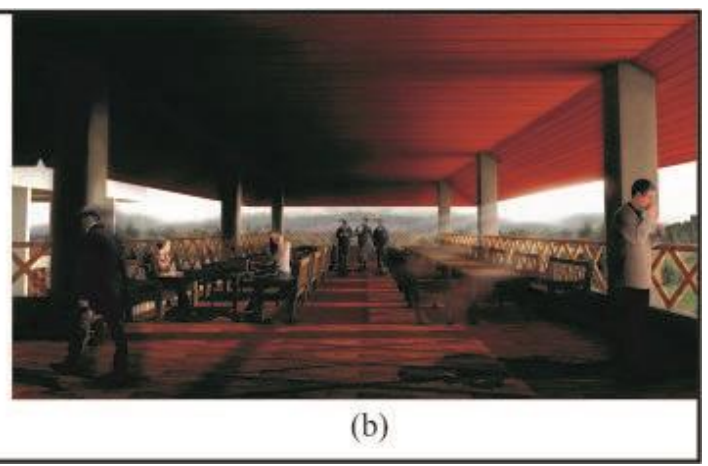

(b)

Figure 16. (a) Exterior perspective and (b) interior perspective with natural nuances

\section{Conclusion}

The green architectural approach can be in line with a natural school concept. Natural school buildings are buildings that are friendly to nature. It also has similarities with the concept of green architecture which makes the emphasis to be environmentally friendly. Green architecture in natural schools can be applied to the use of environmentally friendly materials, natural ventilation systems, environmentally friendly waste treatment, and energy savings. In some cases, a natural school can be incompatible with green architecture. Natural schools that use a lot of wood are not environmentally friendly because the amount of wood has less now. Natural 
schools that make trees very shady to give a natural impression can make the building get no sunlight at all and moist. So, despite giving a natural impression, natural schools can't become environmentally friendly without a green architectural approach.

\section{Acknowledgment}

This article is the result of studies from researchers whose part of their funding needs were financed by the Universitas Sumatera Utara to be donated to the city government. This article in the form of applied research produces a form of planning and design that approach to local wisdom and energy savings.

\section{REFERENCES}

[1] Indonesia, T. R. K. B., Kamus Bahasa Indonesia, Jakarta: Pusat Bahasa Departemen Pendidikan Nasional, 2008.

[2] Wahab, A., Tauhid, F. A. R., \& Arfan, T., "Sekolah Alam di Makassar dengan Konsep Arsitektur Berkelanjutan," Nature: National Academic Journal of Architecture, vol. 1, no. 2, pp. 171-185, 2014.

[3] Karyono, T. H., "Arsitektur Berkelanjutan dan Arsitektur Hijau," in Green Architecture: Pengantar Pemahaman Arsitektur Hijau di Indonesia, Jakarta, Penerbit PT Raja Grafindo Persada, 2010, p. 32.

[4] Karyono, T. H., "Aplikasi Rancangan Arsitektur Hijau di Kawasan Tropis Lembap," in Green Architecture: Pengantar Pemahaman Arsitektur Hijau di Indonesia, Jakarta, Penerbit PT Raja Grafindo Persada, 2010, pp. 133-136.

[5] Lippsmeier, Georg, Tropenbau Building in the Tropics, Bangunan Tropis (terj.), Jakarta: Erlangga, 1994.

[6] Christina, E. M., "Aplikasi Penghematan Energi pada Bangunan," in Hemat Energi \& Lestari Lingkungan Melalui Bangunan, Yogyakarta, Andi, 2013, pp. 63-155.

[7] Akbari, H., Rosenfeld, A. H., \& Taha, H., Summer Heat Islands, Urban Trees, and White Surfaces., 1990.

[8] Nurhapni, N., \& Burhanudin, H., "Kajian Pembangunan Sistem Drainase Berwawasan Lingkungan Di Kawasan Perumahan," Jurnal Perencanaan Wilayah dan Kota, vol. 11, no. $1,2011$.

[9] Christina, E. M., in Hemat Energi \& Lestari Lingkungan Melalui Bangunan, Yogyakarta, Andi, 2013, pp. 94-238.

[10] Karyono, T. H., "Wujud Kota Tropis di Indonesia: Suatu Pendekatan Iklim Lingkungan Dan Energi," DIMENSI (Journal of Architecture and Built Environment), vol. 29, no. 2, 2004.

[11] Lynch, K., The image of the city (Vol. 11), MIT Press, 1960.

[12] Mauliani, L, "Fungsi dan Peran Jalur Pedestrian bagi Pejalan Kaki Sebuah Studi Banding 
Terhadap Fungsi Pedestrian," NALARs, vol. 9, no. 2, 2010.

[13] Ching, F. D., Architecture: Form, space, and order, John Wiley \& Sons, 2014.

[14] Nydia, E. W., Kurnia, R., Firmansyah, A., \& Pratama, R., "Bentuk dan Tata Massa Bangunan Terhadap Kenyamanan Termal Cihampelas Walk Dalam Konteks Sustainable Design," Reka Karsa, vol. 2, no. 2, 2014.

[15] Talarosha, B., "Menciptakan Kenyamanan Thermal dalam Bangunan," Jurnal Sistem Teknik Industri, vol. 6, no. 3, p. 151, 2005.

[16] Luddityawan, A. R., Nugroho, A. M., \& Razziati, H. A., "Taman Vertikal Sebagai Pendinginan Alami Pada Rumah Sederhana Sehat Griya Saxophone Kecamatan Lowokwaru-Kota Malang," Jurnal Mahasiswa Jurusan Arsitektur, vol. 1, no. 1, 2014.

[17] Neufert, E, Data Arsitek Jl. 33, Erlangga, 1996.

[18] Mediastika, C. E., "Desain Jendela Bangunan Domestik untuk Mencapai "cooling ventilation"," DIMENSI (Journal of Architecture and Built Environment), vol. 30, no. 1, 2004.

[19] Frick, I. H., \& Purwanto, L. M. F., Konstruksi Arsitek 1 SISTEM BENTUK STRUKTUR BANGUNAN, Dasar-Dasar Konstruksi Dalam Arsitektur, Kanisius, 1998.

[20] Tangoro, D., Sukardi, K., \& Somaatmadja, A. S., Struktur Bangunan Tinggi dan Bentang Lebar, Jakarta: UI Press, 2006.

[21] Azwarman, A., "Kajian Sumur Resapan Antisipasi Genangan Air pada Perumahan Permata Kenali untuk Pencegahan Banjir," Jurnal Ilmiah Universitas Batanghari Jambi, vol. 15, no. 2, p. 3, 2017.

[22] Harisdani, D. D., \& Lindarto, D., "Partisipasi Masyarakat dalam Penggunaan Teknik Biopori untuk Mengendalikan Banjir Kota (Studi Kasus: kelurahan Tanjung RejoMedan)," NALARs, vol. 17, no. 2, pp. 97-104, 2018.

[23] Lubis, A., "Energi Terbarukan dalam Pembangunan Berkelanjutan," Jurnal Teknologi Lingkungan, vol. 8, no. 2, 2011. 